\title{
Exploration for Ferrous Metals Using Geochemical Soil Survey in Dagbala-Atte District, Southwestern Nigeria
}

\author{
M. O. Adepoju ${ }^{1}$,J. A. Adekoya ${ }^{2}$ and D. R. Awoniran ${ }^{3}$ \\ Department of Applied Geology, The Federal University of Technology, Akure, Nigeria ${ }^{1}$ \\ Department of Geological Sciences, Osun State University, Oshogbo, Nigeria ${ }^{2}$ \\ Department of Remote Sensing and GIS, The Federal University of Technology, Akure, Nigeria ${ }^{3}$
}

\begin{abstract}
Geochemical survey of residual soils to explore for ferrous metals in the more prospective Dagbala-Atte District of Igarra Schist Belt, South western Nigeria was undertaken. The study involved sampling of residual soils from 49 sites; geochemical analysis of the soil samples for 9 elements, namely, $\mathrm{Co}, \mathrm{Cr}, \mathrm{Fe}, \mathrm{Mn}, \mathrm{Mo}, \mathrm{Ni}, \mathrm{Ti}, \mathrm{V}$ and $\mathrm{W}$; and subjecting the geochemical analytical data to both qualitative and statistical analyses which include univariate (histograms and box plots), multivariate statistics (correlation matrix and factor analysis) and construction of geochemical distribution maps. By determining the threshold for each element using the univariate plots, it was possible to isolate elements having anomalous values which were compared with their background concentrations in the World's soils. As a result, only four of the ferrous metals subjected to statistical studies, viz, $\mathrm{Co}, \mathrm{Cr}, \mathrm{Ni}$ and $\mathrm{V}$, were found to have significant anomalous values and are suspected to be mineralized in the district. On the basis of correlation matrix and factor analysis, three groups of element association were recognized, viz, Cr-Ni-V-Ti-Fe, Mn$\mathrm{Co}-\mathrm{Ni}$ and $\mathrm{Mo}-\mathrm{Fe}-\mathrm{V}$ groups. Only one suspected mineralization, viz, $\mathrm{Cr}-\mathrm{Ni}-\mathrm{V}$ mineralization and a Co-Ni anomaly were inferred to be present in the Dagbala-Atte District. With the aid of the elemental geochemical distribution maps the suspected Cr-Ni-V mineralization was linked to the sheared, silicified rock at the northern and southern parts of the district while the suspected Co-Ni anomaly is linked to the quartz-biotite schist at the southwestern part. Based on the foregoing findings, it is recommended that lithogeochemical survey be carried out in the areas circumscribed for the suspected mineralization and anomaly of $\mathrm{Cr}, \mathrm{Ni}, \mathrm{V}$ and $\mathrm{Co}$ in the district.
\end{abstract}

Keywords: Box plots, Factor analysis, Geochemical distribution map, Mineralization

\section{INTRODUCTION}

Ferrous metals include $\mathrm{Fe}$ and other metals like $\mathrm{Co}, \mathrm{Cr}, \mathrm{Mn}, \mathrm{Mo}, \mathrm{Nb}, \mathrm{Ni}, \mathrm{Ta}, \mathrm{Ti}, \mathrm{V}$ and $\mathrm{W}$ that are alloyed with it in specific proportions to produce steel of desired properties. The steel and other alloys of the ferrous metals are employed in industry for production of vehicles, plants and machinery, as well as numerous domestic and industrial appliances. Occurrences of some of these ferrous metals have been variously reported in the Precambrian Basement Complex of Nigeria. For example, iron deposits have been reported at Okene [1], Maru, Birnin Gwari, Muro [2] and Kushaka [3]; Chromium deposit in form of Chromite at Tungan Kudaku [4]; Mn deposit reported at Tudun Kudu [5]; and suspected Ni deposit within the Ilesha Schist Belt $[6,7]$. Most of the reported ferrous metal occurrences are located in the schist belts. This gave impetus to the study of the Igarra Schit Belt for metallic mineralization by $[8,9]$ who discovered that the Dagbala-Atte District within this schist belt has prospects for ferrous metals among others. Hence the principal objective of this study is to conduct a residual soil survey with a view to locating any possible source(s) of the ferrous metals $(\mathrm{Co}, \mathrm{Cr}, \mathrm{Fe}, \mathrm{Mn}, \mathrm{Mo}, \mathrm{Ni}, \mathrm{Ti}, \mathrm{V}$ and $\mathrm{W})$ in the Dagbala-Atte District of Igarra Schist Belt.

\section{GEOLOGICAL SETTING}

Dagbala-Atte District lies within latitude $7^{\circ} 10^{\mathrm{I}} \mathrm{N}$ and $7^{\circ} 21^{\mathrm{I}} \mathrm{N}$ and longitude $6^{\circ} 09^{\mathrm{I}} \mathrm{E}$ and $6^{\circ} 17^{\mathrm{I}} \mathrm{E}$ in the northern part of Edo State, Nigeria (Figures 1 and 2) and covers an area of about $285 \mathrm{~km}^{2}$ within the Igarra Schist Belt, which is surrounded by the older Basement Complex rocks believed to be of Archean to Paleoproterozoic age [10, 11]. Lowgrade metasediments commonly described as the Younger metasediments [12] or Newer metasediments [13] dominate the schist belt. These metasediments consist essentially of a deformed package of pelitic to semi-pelitic schists, marbles, calc-silicate gneiss, quartzites and polymictic metaconglomerates [14-17]. Both the Younger metasediments and the older basement rocks (i.e. the gneisses and migmatites) were intruded by the Pan African granites (also known 


\section{International Advanced Research Journal in Science, Engineering and Technology}

Vol. 6, Issue 3, March 2019

as the Older Granites) represented by the lgarra batholith. Minor felsic and mafic intrusives, including pegmatites, aplite, syenite, lamprophyre and dolerite cross-cut the Pan African granites and the pre-existing rocks.

In the Dagbala-Atte District the rock suites are divisible into the eastern portion dominated by granite gneiss and the western part composed mainly of the Younger metasediments with both portions separated by a narrow zone of silicified, sheared rock (Figure 3) [18]. The metasedimentary package consists predominantly of quartz-biotite, garnetbiotite and mica schists with minor metaconglomerate, quartzites and marble. Both the metasediments and granite gneiss are intruded
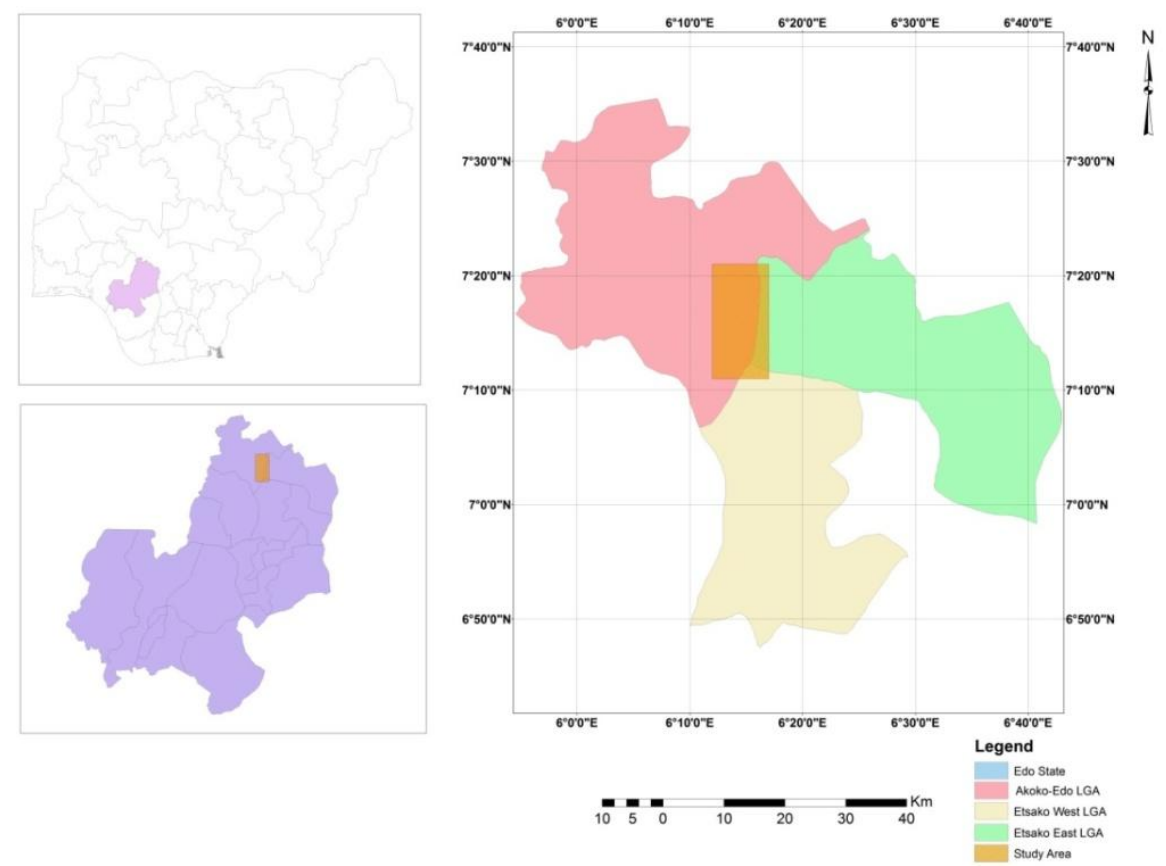

Figure 1: Location Map of the Study Area. Insets: Map of Nigeria showing Edo State and Map of Edo State showing the Location of Dagbala-Atte District.

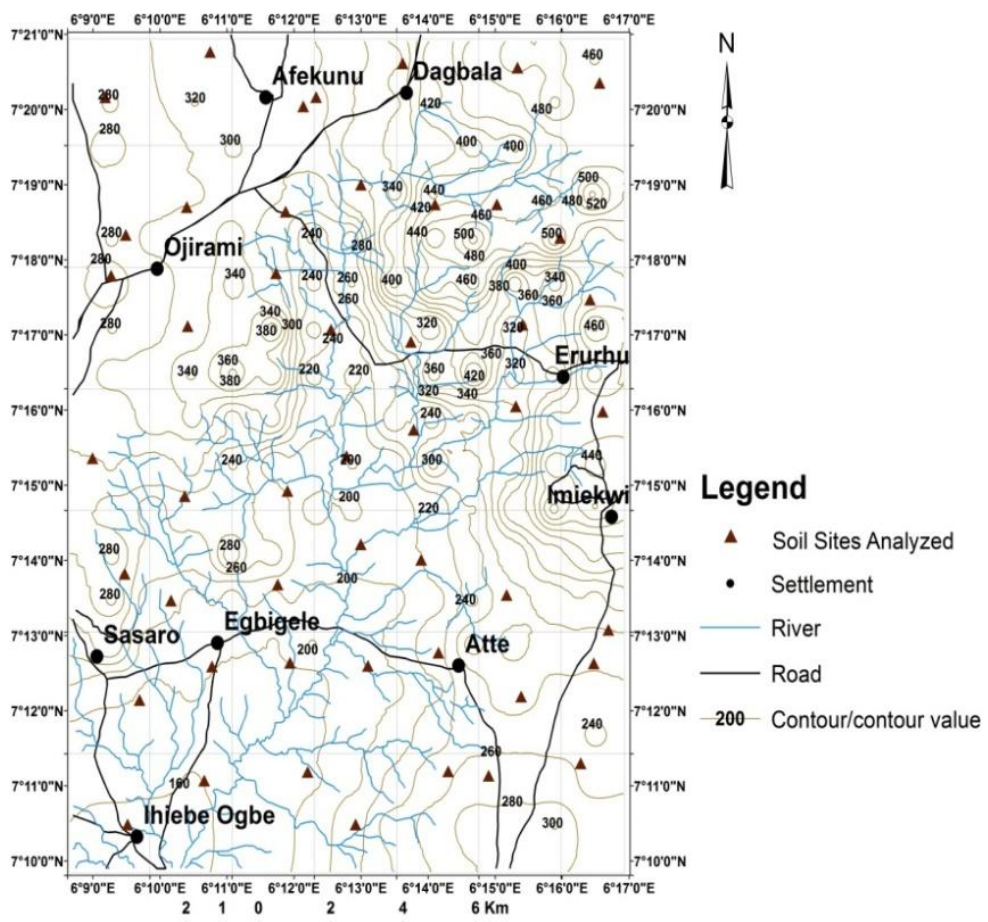

Figure 2. Topographic Map of Dagbala-Atte District Showing the Localities of Forty Nine Soil Samples Employed for this Study. 
Vol. 6, Issue 3, March 2019
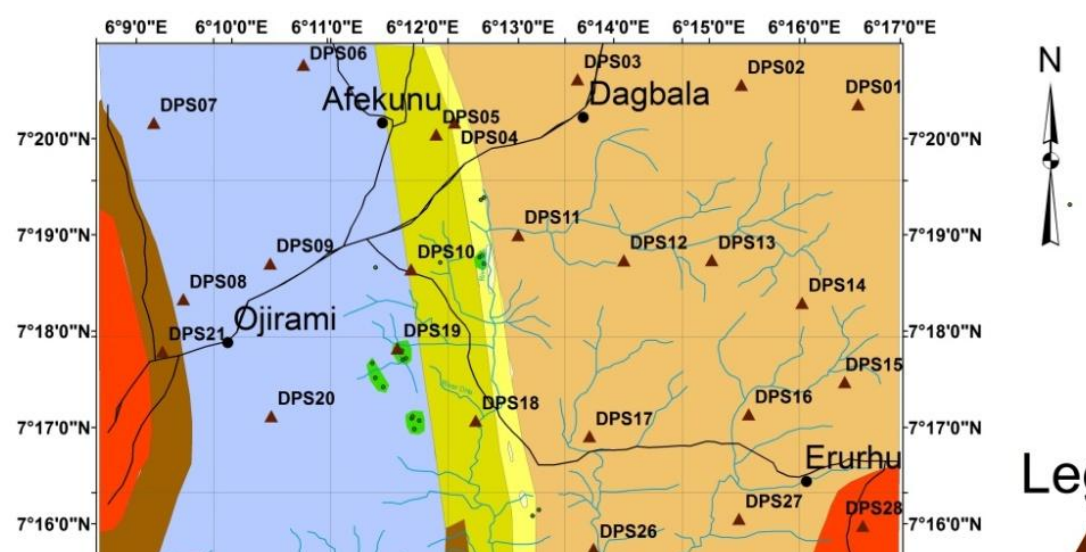

\section{Legend}
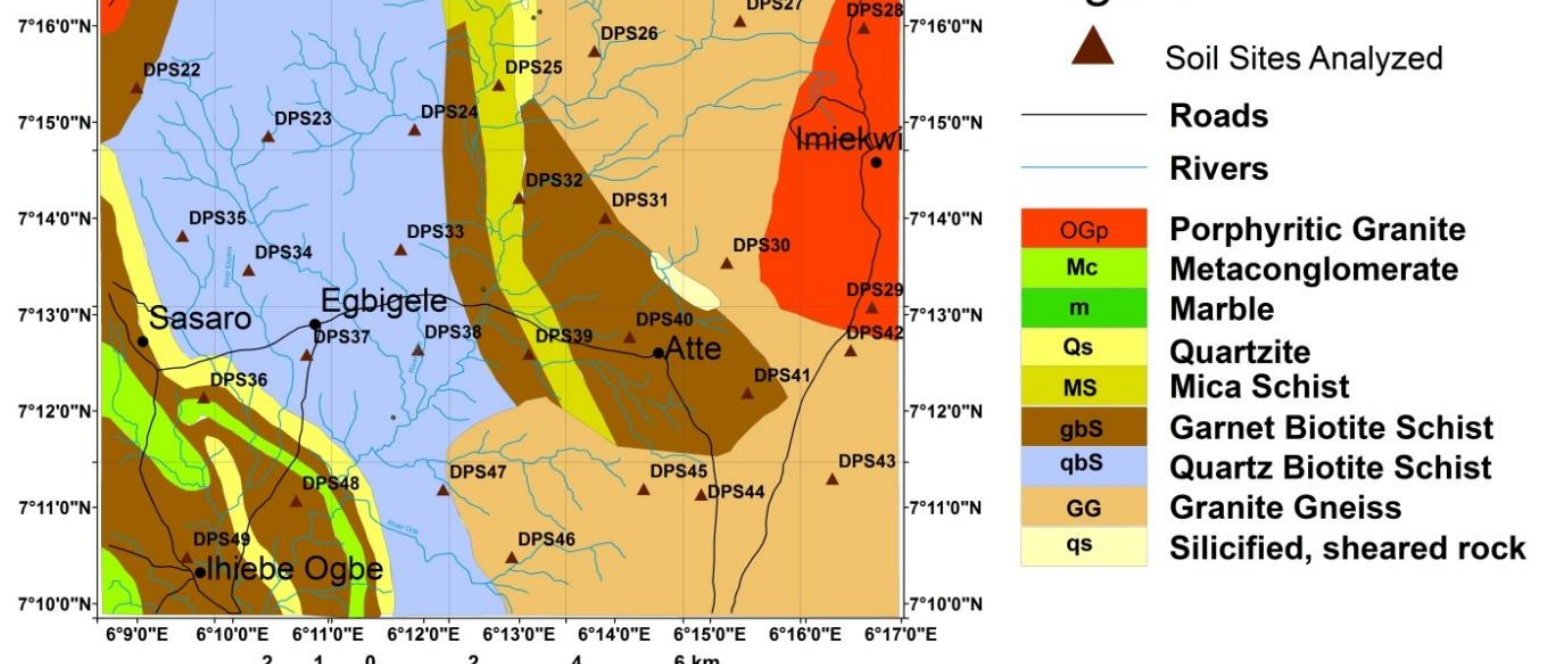

$\begin{array}{llllll}2 & 1 & 0 & 2 & 4 & 6 \mathrm{~km}\end{array}$

Figure 3: Geological map of Dagbala-Atte District Showing the Locations of the Forty-nine Soil Samples in a Grid Pattern (Adapted from [18]).

by porphyritic Pan African granite. All the rock types are affected by intense weathering to varying degrees under the prevailing humid tropical climatic conditions producing ubiquitous residual soil profiles.

\section{METHODOLOGY}

The study involved three stages as follows: (a) sampling of B-horizon soils from the Dagbala-Atte District of $285 \mathrm{~km}^{2}$; (b) geochemical analysis of the soil samples so as to determine the contents of the metals under consideration; and (c) data analysis including qualitative and quantitative analyses.

\section{A. Soil Sampling}

The soil sampling was done in a grid pattern. Hence the study area was divided into approximately $2 \times 3 \mathrm{~km}$ grids on a topographic map of the area. Subsequently, traverse lines were cut on the field to demarcate the grids (Figures 2 and 3 ). Soil sampling was carried out in each grid by driving a 1-meter auger some $20-30 \mathrm{~cm}$ into the ground after ensuring that the top soil was carefully removed at every site. The sites occupied were marked by a labeled stake. It was sometimes necessary to hammer the auger down the soil profile to ensure adequate penetration into the B-horizon, which is preferred in most soil surveys owing to its high accumulation of trace elements [19]. The samples were carefully hammered out of the auger into pre-labeled baft cloth bags. In order to avoid contamination during the sampling operation appropriate care was taken by cleaning the auger with water and ethanol after occupying each grid. For accurate sample site location on the base map a global positioning system (GPS) receiver was used to determine the geographical coordinates of the sites. Forty nine samples were collected and transported to the laboratory. A particular attention was paid to the soil profile being sampled because the target was to sample residual soil, i.e. in situ soil profile, while transported soil was avoided.

\section{B. $\quad$ Geochemical Analysis of the soil samples}

The soil samples were first air dried at room temperature for four weeks, after which they were disaggregated prior to sieving with nylon screen of 200 microns size. The fraction passing through the sieve size was then pulverized to less 


\author{
Vol. 6, Issue 3, March 2019
}

than 75 microns using a porcelain mortar and pestle. All these were done with special care to avoid cross contamination. After the foregoing sample preparation in Nigeria, the soil samples were analyzed at Acme Laboratories, Vancouver, Canada using the following procedures.

Half of a gram $(0.5 \mathrm{~g})$ of each of the pulverized soil samples was weighed into graduated test tubes and $5 \mathrm{ml}$ of 1:1:1 mixture of $\mathrm{HCl}-\mathrm{HNO}_{3}-\mathrm{H}_{2} \mathrm{O}$ (modified aqua regia) was added to the samples. The mixture was heated at $95{ }^{\circ} \mathrm{C}$ for one hour. After the mixture for each sample had cooled down, it was filtered and the leached solution obtained was diluted with ultra-pure water to $10 \mathrm{ml}$. The resulting solutions for all the samples were subjected to elemental analysis using an Inductively-Coupled Plasma Mass Spectrophotometer (ICP-MS) at the Acme Laboratories, Canada. The analytical results of nine elements of interest, namely, $\mathrm{Co}, \mathrm{Cr}, \mathrm{Fe}, \mathrm{Mn}, \mathrm{Mo}, \mathrm{Ni}, \mathrm{Ti}, \mathrm{V}$ and $\mathrm{W}$ are presented in Table 1, which also gives the latitude and longitude of the sampling locations of the 49 residual soil samples for this study.

\title{
C. Data Analysis
}

The analytical results of the elements were subjected to quantitative statistical analysis and other qualitative treatment. The quantitative statistical analysis comprised univariate and multivariate statistics while the qualitative treatment involved plotting geochemical distribution map for the elements. Univariate statistics used here includes histograms and box plots of both raw and log-transformed data. These plots are often useful when combined together to establish the threshold values that will enable the isolation of anomalous concentrations of the elements in the soils of the study area. The multivariate statistics in this paper consists of correlation matrix and factor analysis, which are particularly useful for giving a clue to the interpretation of the elemental associations in the soils of the study area.

\section{Statistical Analysis of Geochemical Data}

Quantitative statistical analysis employed in this study is widely used as a useful and necessary technique in interpretation of geochemical data [8, 20-23]. Histograms, box plots, correlation matrix and factor analysis were constructed using the analytical results with the help of a software package - Minitab-16 in a DELL Inspiron 5521 Laptop computer. Both the histograms and box plots were done using the raw and log-transformed geochemical data. A summary of the basic statistics and other parameters derived from the histograms (means and standard deviations) and the box plots (1st quartiles, $\mathrm{Q}_{1}$; 3rd quartiles, $\mathrm{Q}_{3}$; and interquartile range, $\mathrm{Q}_{3}-\mathrm{Q}_{1}$ ) is tabulated for 8 elements excluding $\mathrm{W}$ that is detected in only six of the 49 sites involved in the present study (Table 2).

The prime assumption underlying the application of the multivariate methods of correlation matrix (CM) and factor analysis (FA) is for the data to follow normal distribution. The raw datasets of the elements in the district are nonnormal, but their logarithmically transformed datasets are normal. Therefore the logarithmically transformed data are employed for the determination of CM and FA. Another crucial assumption in multivariate statistics is that the element to be subjected to it must not contain more than $30 \%$ censored data (i.e. values below the analytical detection limit (DL) of the analytical facility and are given as less than the DLs for the element). Hence W that was detected at only six of the 49 sample sites employed for this study is exempted from the determination of CM and FA. For Mo that contains only 1 censored value, a value equal to $66 \%$ of its lower DL was substituted [24] for the computation of CM and FA. Therefore, CM and FA were constructed for the logarithmically transformed analytical results of eight elements save $\mathrm{W}$ for this study.

\section{E. $\quad$ Plotting of Geochemical Distribution Map}

The distribution maps of the elements in the soils of the district based on the raw data in Table 1 and the soil sample location map of the study area (Figure 2) drawn using Arc-GIS 10.4.1 program in a DELL Inspiron 5521 Laptop computer have been used to explain the distribution of the various elements in the soils of the study area.

\section{RESULTS AND DISCUSSION}

\section{A. Histograms}

The histogram is one of the most popular graphical means of displaying distribution since it reflects the shape similar to theoretical frequency distributions. Histograms plotted on raw data show positive skewness of the elements in varying degrees while those plotted on the log-transformed data display no skewness and the curves superimposed on them are essentially bell-shaped, which indicates that the distribution of the elements are log-normal. Examples of these two sets of histograms are presented in Figure 4. Some of the raw data histograms show breaks in distribution, which might be interpreted as revealing mixtures of populations e.g. in $\mathrm{Cr}$, Fe, Mo and V histograms. However, the log-transformed data histograms only show breaks in distribution for Co.

\section{B. Box Plots}

The box plot is a method used to display some statistical parameters in a graphical form [25]. Provided the scale of presentation is reasonable, the box plot provides a fast visual estimate of the frequency distribution. Examples of the dispersion box plots of the trace metals based on both the raw and log-transformed data are presented in Figures 5 . The 
Vol. 6, Issue 3, March 2019

raw data box plots (Figure 5 a) show longer whiskers above the mean and shorter ones below it. This implies that most of the values of the elements greatly depart from the mean, which is also an indication of the extreme variability of geochemical data. This trend in any data set indicates non-normal situation. In the case of the log-transformed dispersion box plots (Figures $5 \mathrm{~b}$ ) a more refined dataset resulted with both the maximum and minimum values evenly distributed about the mean value. This provided a data set with a smaller and more stable variance which aided greatly in data analysis. Each of the raw data and logarithmically transformed data plots shows the number of samples that contain anomalous concentrations of elements, called outlier values in the box plots (Figures 5 a and 5 b).

Table 1: Raw Concentrations in ppm of Ferrous Metals in Soils of Dagbala-Atte District.

\begin{tabular}{|c|c|c|c|c|c|c|c|c|c|c|c|}
\hline Sample No & Longitude & Latitude & Co & $\mathrm{Cr}$ & $\mathrm{Fe}$ & $\mathrm{Mn}$ & Mo & $\mathrm{Ni}$ & $\mathrm{Ti}$ & $\mathrm{V}$ & $\mathrm{W}$ \\
\hline DPS01 & 6.27601 & 7.33925 & 6.9 & 6.2 & 1.9 & 80 & 2.25 & 2.7 & 0.028 & 12 & $<0.1$ \\
\hline DPS02 & 6.25559 & 7.34263 & 12.3 & 6.2 & 0.87 & 480 & 0.34 & 3.8 & 0.013 & 12 & $<0.1$ \\
\hline DPS03 & 6.22703 & 7.34360 & 8.2 & 33.1 & 2.64 & 381 & 1.21 & 12.5 & 0.04 & 54 & $<0.1$ \\
\hline DPS04 & 6.20553 & 7.33612 & 2.7 & 30.5 & 2.64 & 263 & 0.98 & 10.4 & 0.029 & 47 & $<0.1$ \\
\hline DPS05 & 6.20233 & 7.33403 & 5 & 13.1 & 0.83 & 120 & 0.17 & 3.5 & 0.023 & 17 & $<0.1$ \\
\hline DPS06 & 6.17917 & 7.34610 & 2.1 & 30.2 & 2.12 & 158 & 0.33 & 11.4 & 0.037 & 46 & $<0.1$ \\
\hline DPS07 & 6.15307 & 7.33607 & 5.1 & 17 & 0.7 & 107 & 0.07 & 4.5 & 0.034 & 19 & $<0.1$ \\
\hline DPS08 & 6.15820 & 7.30553 & 0.5 & 6.2 & 0.37 & 230 & 0.11 & 2.2 & 0.006 & 9 & $<0.1$ \\
\hline DPS09 & 6.17338 & 7.31172 & 12.2 & 5.4 & 0.12 & 16 & $<0.01$ & 1.3 & 0.007 & 4 & $<0.1$ \\
\hline DPS10 & 6.19797 & 7.31070 & 1.8 & 46.7 & 2.83 & 296 & 0.27 & 30.7 & 0.133 & 49 & 0.1 \\
\hline DPS11 & 6.21667 & 7.31667 & 4.1 & $340.2^{*}$ & 4.43 & 21 & 0.45 & 10.1 & 0.052 & 128 & $<0.1$ \\
\hline DPS12 & 6.23509 & 7.31228 & 3.5 & 7.4 & 1.12 & 673 & 1.08 & 3.9 & 0.016 & 14 & $<0.1$ \\
\hline DPS13 & 6.25047 & 7.31230 & 1.9 & 14.1 & 1.46 & 279 & 0.79 & 3.8 & 0.018 & 16 & $<0.1$ \\
\hline DPS14 & 6.26623 & 7.30491 & 3.9 & 12.4 & 1.49 & 116 & 0.64 & 4.7 & 0.056 & 21 & $<0.1$ \\
\hline DPS15 & 6.27367 & 7.29119 & 7.3 & 8.3 & 3.6 & 459 & 2.5 & 3.9 & 0.051 & 16 & $<0.1$ \\
\hline DPS16 & 6.25689 & 7.28561 & 11.9 & 24.6 & 5.49 & 427 & 2.46 & 9.6 & 0.084 & 60 & $<0.1$ \\
\hline DPS17 & 6.22911 & 7.28183 & 8.9 & 59.5 & 2.55 & 315 & 0.11 & 21.1 & 0.206 & 42 & 0.4 \\
\hline DPS18 & 6.20923 & 7.28452 & 10.3 & 34.1 & 2.1 & 312 & 0.55 & 19.8 & 0.125 & 40 & 0.1 \\
\hline DPS19 & 6.19558 & 7.29703 & 2.1 & 46.3 & 2.21 & 356 & 0.15 & 23.4 & 0.165 & 45 & 0.1 \\
\hline DPS20 & 6.17358 & 7.28531 & 6.4 & 10.2 & 0.35 & 37 & 0.04 & 3.6 & 0.015 & 13 & $<0.1$ \\
\hline DPS21 & 6.15455 & 7.29648 & 4.9 & 19.1 & 1.17 & 386 & 0.32 & 7.6 & 0.033 & 27 & $<0.1$ \\
\hline DPS22 & 6.14990 & 7.25602 & 14.5 & 12 & 0.66 & 210 & 0.15 & 4 & 0.02 & 13 & $<0.1$ \\
\hline DPS23 & 6.17286 & 7.24761 & 9.5 & 57.3 & 3.34 & 502 & 0.41 & 36.8 & 0.236 & 67 & $<0.1$ \\
\hline DPS24 & 6.19840 & 7.24875 & 7.8 & 43.5 & 1.8 & 402 & 0.31 & 16.9 & 0.105 & 51 & $<0.1$ \\
\hline DPS25 & 6.21308 & 7.25647 & 12.8 & 7.5 & 0.52 & 264 & 0.2 & 2.8 & 0.01 & 12 & $<0.1$ \\
\hline DPS26 & 6.22980 & 7.26231 & 10.2 & 54.7 & 2.5 & 496 & 0.3 & 12.3 & 0.096 & 45 & $<0.1$ \\
\hline DPS27 & 6.25521 & 7.26753 & 9.5 & 13.5 & 2.16 & 893 & 1.08 & 6.8 & 0.077 & 23 & $<0.1$ \\
\hline DPS28 & 6.27683 & 7.26634 & 6.7 & 9.8 & 8.12 & 983 & 2.16 & 5.3 & 0.296 & 34 & $<0.1$ \\
\hline DPS29 & 6.27823 & 7.21795 & 8.3 & 25.4 & 3.97 & 374 & 1.03 & 10.5 & 0.039 & 23 & $<0.1$ \\
\hline DPS30 & 6.25292 & 7.22567 & 8.5 & 19.8 & 2.2 & 268 & 0.97 & 7.8 & 0.013 & 43 & $<0.1$ \\
\hline DPS31 & 6.23168 & 7.23347 & 13.7 & 44.4 & 2.72 & 286 & 0.6 & 20.6 & 0.06 & 60 & $<0.1$ \\
\hline DPS32 & 6.21665 & 7.23692 & 12.5 & 42.6 & 3.43 & 288 & 0.46 & 28.4 & 0.099 & 61 & $<0.1$ \\
\hline DPS33 & 6.19598 & 7.22800 & 14.2 & 140.3 & 2.29 & 483 & 0.31 & 46.2 & 0.136 & 51 & 0.1 \\
\hline DPS34 & 6.16945 & 7.22443 & 18.4 & 63.7 & 2.79 & 658 & 0.37 & 27.8 & 0.096 & 54 & $<0.1$ \\
\hline DPS35 & 6.15790 & 7.23035 & 6.9 & 83.1 & 3.6 & 804 & 0.38 & 34 & 0.24 & 71 & $<0.1$ \\
\hline DPS36 & 6.16160 & 7.20237 & 9.2 & 18.1 & 1.19 & 208 & 0.21 & 9.3 & 0.038 & 25 & $<0.1$ \\
\hline DPS37 & 6.17962 & 7.20980 & 4.2 & 10 & 0.86 & 306 & 0.31 & 3.8 & 0.011 & 16 & $<0.1$ \\
\hline DPS38 & 6.19903 & 7.21065 & 11.1 & 115.2 & 12.33 & 127 & 2.82 & 10.5 & 0.029 & 128 & $<0.1$ \\
\hline DPS39 & 6.21840 & 7.20993 & 5.2 & 40 & 2.26 & 382 & 0.23 & 21.5 & 0.072 & 43 & $<0.1$ \\
\hline DPS40 & 6.23597 & 7.21285 & 8.6 & 23.3 & 1.27 & 213 & 0.22 & 9.6 & 0.049 & 21 & $<0.1$ \\
\hline DPS41 & 6.25653 & 7.20315 & 10.5 & 11.7 & 1.51 & 296 & 0.46 & 5.6 & 0.017 & 27 & $<0.1$ \\
\hline DPS42 & 6.27455 & 7.21050 & 12.6 & 10.3 & 2.9 & 1159 & 0.81 & 5.6 & 0.086 & 22 & $<0.1$ \\
\hline DPS43 & 6.27132 & 7.18831 & 10.5 & 22.7 & 2.13 & 512 & 0.74 & 11.5 & 0.015 & 42 & $<0.1$ \\
\hline DPS44 & 6.24842 & 7.18557 & 6.3 & 15.7 & 1.62 & 451 & 0.44 & 6.3 & 0.017 & 31 & $<0.1$ \\
\hline DPS45 & 6.23840 & 7.18655 & 13.3 & 43 & 5.84 & 302 & 1.31 & 10.9 & 0.022 & 62 & $<0.1$ \\
\hline DPS46 & 6.21537 & 7.17475 & 8.5 & 40.7 & 2.39 & 493 & 0.23 & 16.5 & 0.051 & 48 & $<0.1$ \\
\hline DPS47 & 6.20342 & 7.18643 & 8.6 & 25.5 & 2.09 & 646 & 0.78 & 9 & 0.016 & 29 & 0.1 \\
\hline DPS48 & 6.17772 & 7.18448 & 8.2 & 26.1 & 1.72 & 254 & 0.24 & 10.9 & 0.053 & 36 & $<0.1$ \\
\hline DPS49 & 6.15867 & 7.17477 & 6.9 & 23.3 & 1.12 & 289 & 0.16 & 11.6 & 0.049 & 25 & $<0.1$ \\
\hline
\end{tabular}

Table 2: Summary Statistics for residual soils in Dagbala-Atte District, Nigeria 
International Advanced Research Journal in Science, Engineering and Technology

Vol. 6, Issue 3, March 2019

\begin{tabular}{|l|l|l|l|l|l|l|l|l|l|l|}
\hline Elem & $\mathrm{N}$ & Mean & StDev & Min. & Q1 & Median & Q3 & Max. & Th $\left(10^{\text {x+2sd }}\right)$ & Th(10 $\left.{ }^{\text {Q3+1.5TRR }}\right)$ \\
\hline $\mathrm{Co}$ & 49 & 0.8271 & 0.3051 & -0.301 & 0.6946 & 0.9191 & 1.0333 & 1.2648 & 27.3714 & 34.78 \\
\hline $\mathrm{Cr}$ & 49 & 1.3723 & 0.3864 & 0.7324 & 1.0737 & 1.3674 & 1.6360 & 2.5317 & 139.669 & 301.6 \\
\hline $\mathrm{Fe}$ & 49 & 0.2650 & 0.3556 & -0.921 & 0.0719 & 0.3284 & 0.4487 & 1.0910 & 9.4667 & 10.33 \\
\hline $\mathrm{Mn}$ & 49 & 2.4522 & 0.3745 & 1.2041 & 2.3451 & 2.4857 & 2.6826 & 3.0641 & 1589 & 1545 \\
\hline $\mathrm{Mo}$ & 48 & - & 0.4872 & -2.181 & -0.648 & - & -0.052 & 0.4502 & 3.7888 & 6.932 \\
& & 0.3959 & & & & 0.4202 & & & & \\
\hline $\mathrm{Ni}$ & 49 & 0.9496 & 0.3545 & 0.1139 & 0.6276 & 0.9823 & 1.2227 & 1.6646 & 45.5617 & 130.4 \\
\hline $\mathrm{Ti}$ & 49 & - & 0.4205 & - & -1.757 & - & -1.042 & - & 0.2920 & 1.076 \\
& & 1.3756 & & 2.2218 & & 1.3979 & & 0.5287 & & \\
\hline $\mathrm{V}$ & 49 & 1.4844 & 0.3002 & 0.6021 & 1.2546 & 1.5315 & 1.6989 & 2.1072 & 121.563 & 231.9 \\
\hline
\end{tabular}
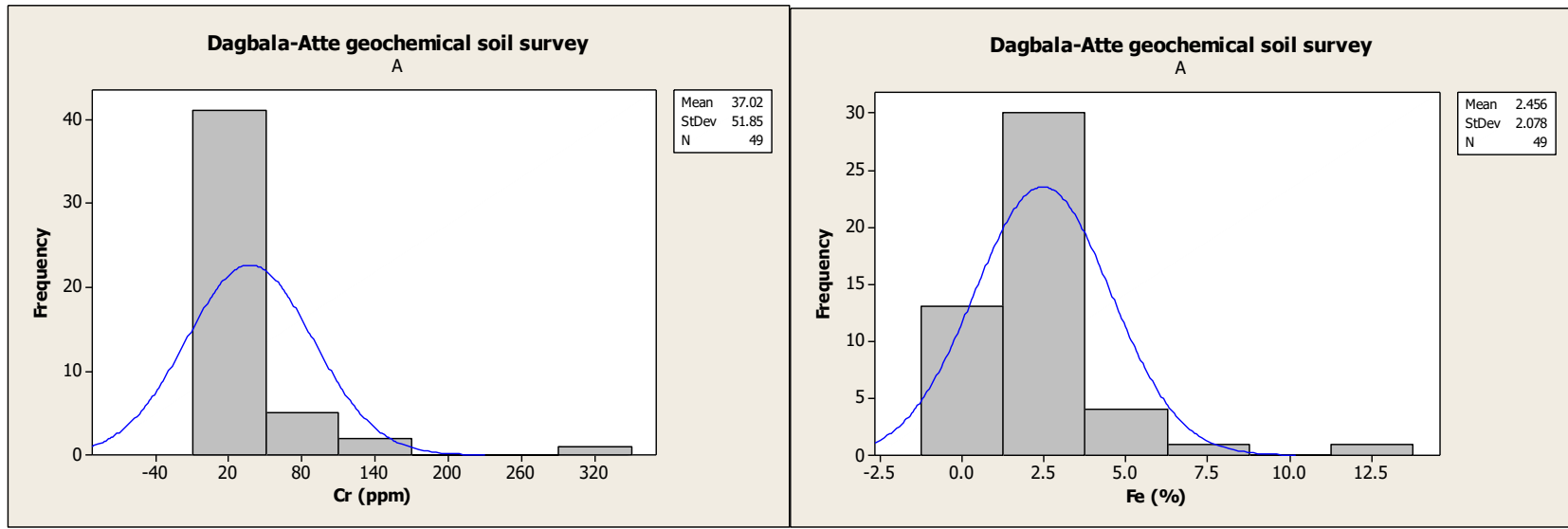

(a)
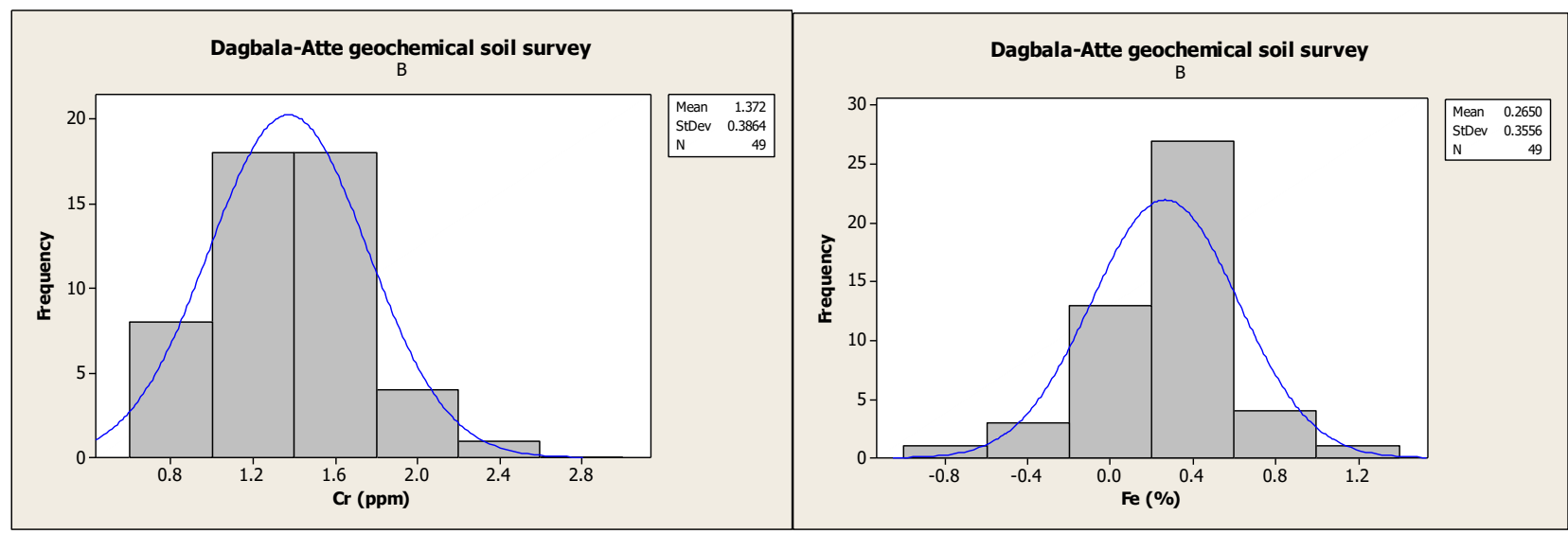

(b)

Figure 4: Histograms of (a) Raw and (b) Logarithmically Transformed Concentrations of Cr and Fe in Soils of Dagbala-Atte District.

C. $\quad$ Statistical Summary Table

Table 2 is a statistical summary table for 8 of the 9 elements employed for this study. The table lists minimum, maximum and mean values, $1^{\text {st }}$ quartile $\left(Q_{1}\right)$, median, $3^{\text {rd }}$ quartile $\left(Q_{3}\right)$, interquartile range $\left(Q_{3}-Q_{1}\right)$, standard deviation for the elements and threshold values. The list also includes threshold values calculated using formulae - Mean + $2 *$ Standard deviation and Q3 $+1.5 *$ interquartile range, for the logarithmically transformed data since the elements in the soils of the study area are log-normally distributed. However, the threshold computed from the formula Mean + $2 *$ Standard deviation was preferred for this study (Table 2) because it gave the lower threshold values for all the elements except $\mathrm{Mn}$, which increases the chances of having more sites that can be considered anomalous. 
International Advanced Research Journal in Science, Engineering and Technology

Vol. 6, Issue 3, March 2019
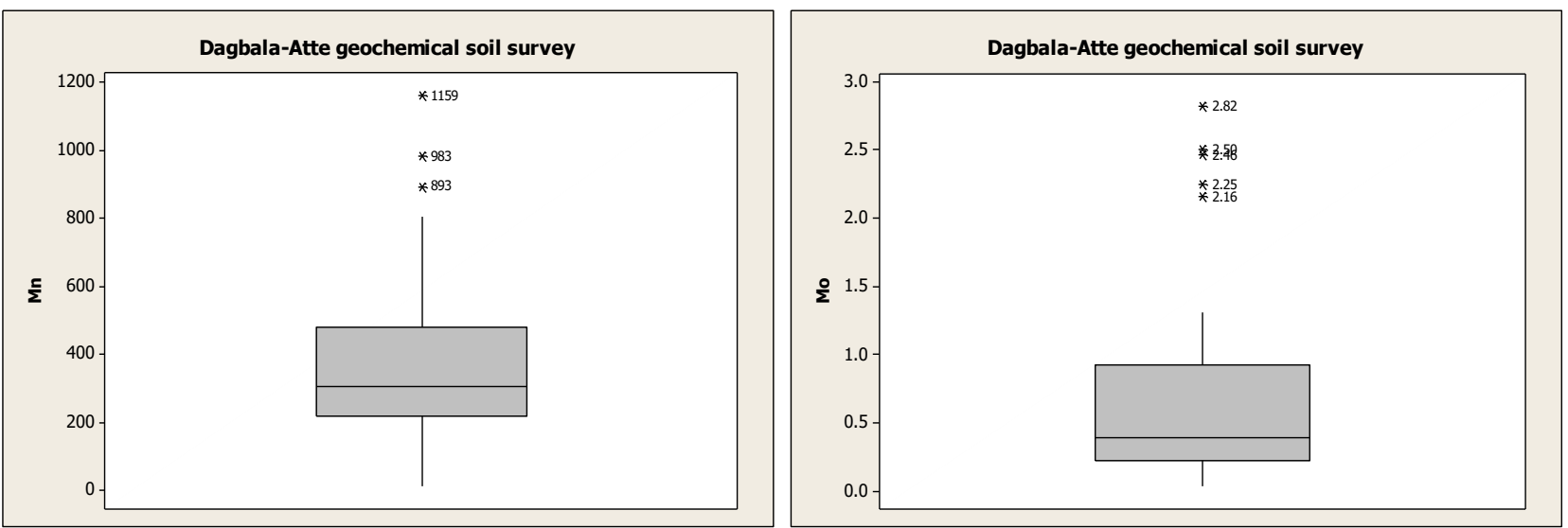

(a)
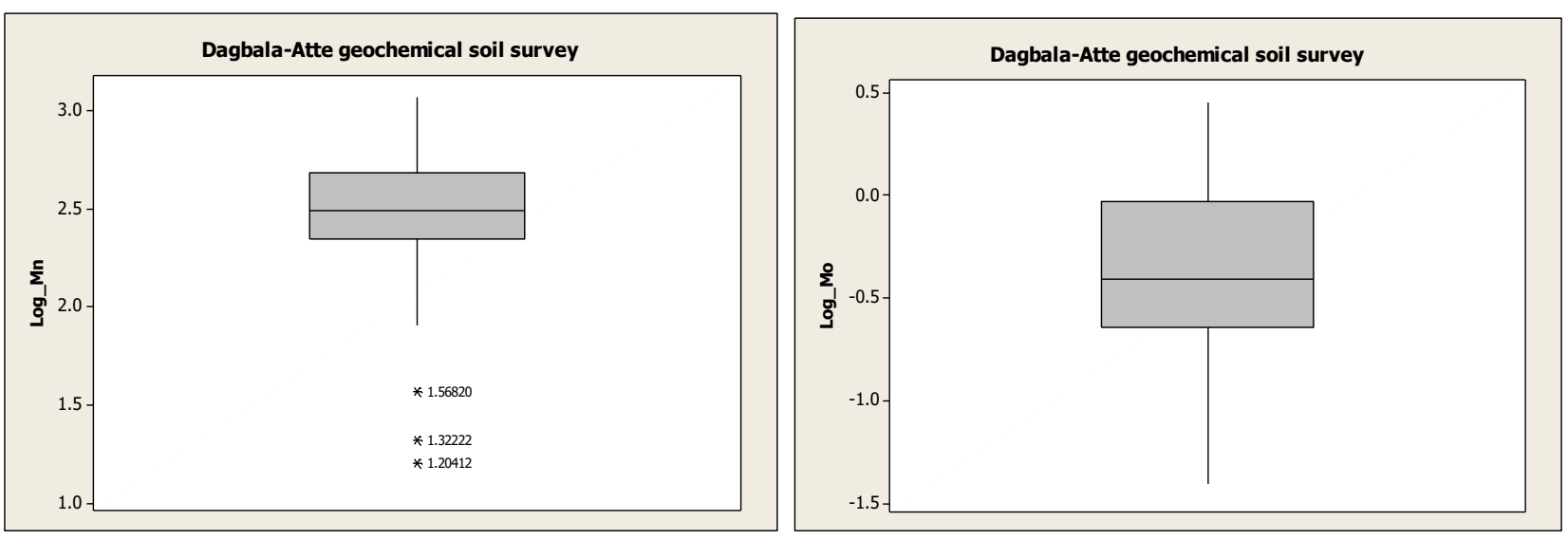

(b)

Figure 5 A: Boxplot of (a) Raw and (b) Logarithmically Transformed Concentrations of Mn and Mo in Soils of Dagbala-Atte District.

\section{Correlation Matrix}

Table 3 shows the correlation matrix of the eight elements in the Dagbala-Atte soil geochemical data. The matrix of simple correlation coefficients shows a fairly strong positive correlation between most metals and weak negative correlation between others. It was observed that all the correlation coefficients between metals were significant at $95 \%$ confidence level and above. The best correlation ( $\mathrm{r} \geq 0.75$ ) occurs between Co-Mn, Cr-Ni, Cr-V, Fe-Mo, Fe-V and Ni$\mathrm{V}$; very good correlation $(0.65 \leq \mathrm{r}<0.75)$ exists between each of Co-Ni and Ti-Ni; good correlation $(0.55 \leq \mathrm{r}<0.65)$ occurs between each of $\mathrm{Co}-\mathrm{Ti}, \mathrm{Cr}-\mathrm{Ti}$, Fe-Ti, $\mathrm{Cr}-\mathrm{Fe}, \mathrm{Fe}-\mathrm{Ni}$ and $\mathrm{Ti}-\mathrm{V}$; and fairly good correlation $(0.35 \leq \mathrm{r}<0.55)$ exist between Co-Cr, Co-Fe, Co-Ti, Co-V, Mn-Mo, Fe-Mn, Mo-V, Mn-Ni, Mn-V and Ti-Mn.

\section{E. Factor Analysis}

Table 4 (a) is the rotated varimax factor matrix. The factor solutions provided information on eigenvalues (the amount of the total data explained by each model) and communalities (the amount of the total variability of each element explained in a given factor model) for the factor model obtained. Table 4 (a) gave a three-factor model presented in Table 4 (b). The total explained variance of the three-factor model is $91.3 \%$ (Table 4 (b). Table 4 (a) also shows that each factor consists of significant contributions from certain variables and less important to negligible contributions from others. In summary, Factor 1 is a Cr-Ni-V-Ti-Fe factor, Factor 2, a Mn-Co-Ni factor and Factor R-3, a Mo-Fe-V factor.

Table 3: Pearson Correlation Matrix of the elements for Log-Data of Soils in Dagbala-Atte District

\begin{tabular}{|l|l|l|l|l|l|l|l|l|}
\hline & $\mathrm{Co}$ & $\mathrm{Cr}$ & $\mathrm{Fe}$ & $\mathrm{Mn}$ & $\mathrm{Mo}$ & $\mathrm{Ni}$ & $\mathrm{Ti}$ & $\mathrm{V}$ \\
\hline $\mathrm{Co}$ & 1 & & & & & & & \\
\hline $\mathrm{Cr}$ & 0.379 & 1 & & & & & & \\
\hline $\mathrm{Fe}$ & 0.494 & 0.609 & 1 & & & & & \\
\hline $\mathrm{Mn}$ & 0.827 & 0.031 & 0.442 & 1 & & & & \\
\hline $\mathrm{Mo}$ & 0.309 & 0.116 & 0.776 & 0.481 & 1 & & & \\
\hline
\end{tabular}


International Advanced Research Journal in Science, Engineering and Technology

Vol. 6, Issue 3, March 2019

\begin{tabular}{|l|l|l|l|l|l|l|l|l|}
\hline $\mathrm{Ni}$ & 0.703 & 0.831 & 0.603 & 0.394 & 0.147 & 1 & & \\
\hline $\mathrm{Ti}$ & 0.494 & 0.576 & 0.612 & 0.390 & 0.194 & 0.745 & 1 & \\
\hline $\mathrm{V}$ & 0.543 & 0.887 & 0.819 & 0.244 & 0.423 & 0.820 & 0.598 & 1 \\
\hline
\end{tabular}

Table 4: (a) Varimax Rotated Factor Loadings and Communalities, (b) Element Associations of the Three-factor Model for the soils of Dagbala-Atte District.

(a)

\begin{tabular}{|l|l|l|l|l|}
\hline Variable & Factor1 & Factor2 & Factor3 & Communality \\
\hline $\mathrm{Co}$ & 0.398 & -0.864 & 0.116 & 0.918 \\
\hline $\mathrm{Cr}$ & 0.961 & 0.046 & 0.099 & 0.936 \\
\hline $\mathrm{Fe}$ & 0.585 & -0.218 & 0.759 & 0.965 \\
\hline $\mathrm{Mn}$ & 0.021 & -0.937 & 0.297 & 0.967 \\
\hline $\mathrm{Mo}$ & 0.030 & -0.214 & 0.965 & 0.978 \\
\hline $\mathrm{Ni}$ & 0.886 & -0.403 & 0.015 & 0.949 \\
\hline $\mathrm{Ti}$ & 0.710 & -0.380 & 0.091 & 0.657 \\
\hline $\mathrm{V}$ & 0.874 & -0.116 & 0.396 & 0.934 \\
\hline Variance & 3.4784 & 2.0400 & 1.7844 & 7.3028 \\
\hline \% Var & 0.435 & 0.255 & 0.223 & 0.913 \\
\hline
\end{tabular}

(b)

\begin{tabular}{|l|l|l|}
\hline Factor & Elements & Eigen Value (\%) \\
\hline F-1 & Cr-Ni-V-Ti-Fe & 43.5 \\
\hline F-2 & Mn-Co-Ni & 25.5 \\
\hline F-3 & Mo-Fe-V & 22.3 \\
\hline
\end{tabular}

Factor F-1 is the most pronounced and accounts for $43.5 \%$ of the three-factor model in the area. It is interpreted to indicate probably a $\mathrm{Cr}-\mathrm{Ni}$ concentration, possibly a mineralization, in a mafic--ultramafic igneous body. The occurrence of $\mathrm{V}, \mathrm{Ti}$ and $\mathrm{Fe}$ in this factor lends credence to the postulation of a $\mathrm{Cr}-\mathrm{Ni}$ - bearing igneous body in the study area because the three elements are often found associated together in magnetite, hematite and ilmenite especially in basic igneous rocks. Hence they can serve as pathfinder elements for the $\mathrm{Cr}-\mathrm{Ni}$ mineralization. The association of the 5 elements $(\mathrm{Cr}, \mathrm{Ni}, \mathrm{V}, \mathrm{Ti}$ and $\mathrm{Fe})$ in this factor is to be expected because of the substitution that can occur in their common trivalent state and similarity in ionic radii. For example, $\mathrm{V}$ is commonly present in ilmenite $(\mathrm{FeTiO})_{3}$, the titanium mineral and it replaces $\mathrm{Cr}$ easily. However, the presence of $\mathrm{Fe}$ in this factor raises the possibility of scavenging action of the metal on or co-precipitation with other elements associated with it in the factor model, given the fact that the residual soil environment is a secondary geochemical environment where either of those activities can easily take place. However, the low loading of Mn (0.021) compared with the relatively high loading of Fe $(0.585)$ in the same factor model renders the scavenging or co-precipitation possibility unlikely. In addition the relatively low correlation coefficient $(0.442)$ between the two elements suggests that the likelihood of environmental influence involving the well-known sympathetic behavior of the two elements in the secondary (soil) geochemical environment is low. If these propositions are correct, one can surmise that the association of Fe with other elements in the factor model is probably not influenced by the scavenging action of or co-precipitation with Fe in the secondary (soil) environment but rather more profoundly controlled by inheritance of the elements from the bedrock from which the residual soil is derived.

Factor F-2 also accounts for $25.5 \%$ of the model variance and was interpreted mainly as a Co-Ni concentration with which $\mathrm{Mn}$ is associated. The association of $\mathrm{Co}$ and $\mathrm{Mn}$ is to be expected because Co co-precipitates with $\mathrm{Mn}$ oxyhydroxides [26]. Therefore, the presence of $\mathrm{Mn}$ in this factor suggests the possibility of its scavenging action on Co being at play under the secondary geochemical environment of the residual soils. The high negative loading of both Co and $\mathrm{Mn}$ in this factor suggests strongly that the two elements had similar sources, presumably local surficial or superficial origin influenced by the secondary geochemical factors of the soil environment.

Factor F-3 accounts for $22.3 \%$ of the total explained variance in the study area. It is interpreted as a Mo factor with association of $\mathrm{Fe}$ and $\mathrm{V}$. It indicates the association of $\mathrm{Mo}, \mathrm{Fe}$ and $\mathrm{V}$ in some portion of the rocks of the district. The high loading of Mo (0.965) and Fe (0.759) in the factor model strongly suggests that the reaction of Mo with Fe oxides to form ferrimolybdite (a common molybdenum-bearing weathering product) is at play in the soil environment. Therefore, the association of the elements in Factor-3 model would appear to be controlled by the weathering environmental factors. However, the elements of the different associations in the residual soils of the district are assumed to be derived from the rocks of the district because residual soils are direct products of weathering of the underlying rocks. 


\title{
International Advanced Research Journal in Science, Engineering and Technology
}

\author{
Vol. 6, Issue 3, March 2019
}

\section{F. Geochemical Distribution of the Elements in Soils of Dagbala-Atte District}

The geochemical distribution maps of the elements in the soils of the district (examples shown in Figure 6) have been employed to explain the distribution of the various elements in the residual soils of the study area. To ensure that the anomalous sites, selected on the basis of the threshold values fixed for the elements, are meaningful these threshold values were compared with the background concentrations of selected trace elements in the World's soils (Table 5) [19, 26]. Where the concentration of any element in an anomalous site is lower than the average world soil's background value (Table 5) such an anomalous site was considered insignificant.

Co shows a wide distribution in the study area and it is detected in all the 49 samples employed for this study. Its concentrations in this area range from 0.5 to $18.4 \mathrm{ppm}$. At threshold value of $27.4 \mathrm{ppm}$, Co has no anomalous site in the study area. Co distribution map (Figure 6a) shows the higher values of the element at sites DPS31, DPS33, DPS34 and DPS45 that are underlain by garnet biotite schist (DPS 31), quartz biotite schist (DPS33 and DPS34) and granite gneiss (DPS45) (Fig. 3). The value at DPS 34 (18.4 ppm) is somewhat higher than the average value of Co (10 ppm) in the world's soils. This fairly high value may be due to some concentration of Co in the soil environment possibly as a result of the scavenging action of $\mathrm{Mn}$ with which it is associated. The best correlation of cobalt with Mn and very good correlation with $\mathrm{Ni}$, as well as the association of cobalt with these two elements in Factor F-2 supports the inferred secondary geochemical environmental control of the element association involving $\mathrm{Co}, \mathrm{Mn}$ and $\mathrm{Ni}$ in the residual soil. $\mathrm{Cr}$ distribution map is shown in Figure $6 \mathrm{~b}$. Its contents vary from 5.4 to $340.2 \mathrm{ppm}$ with a mean of 37 ppm. Two anomalous values of chromium exist above a threshold value of $139.7 \mathrm{ppm}$ at sites DPS11 located within the silicified sheared rock and DPS33 underlain by quartz-biotite schist (Fig. 3). When the mean content of Cr in this area is compared with its background concentration in soils (Table 5), the anomalous value at DPS11 appears to be the only significant one. This indicates that there might be a $\mathrm{Cr}$ mineralization at site DPS11 underlain by silicified, sheared rock. The best correlation that exists between $\mathrm{Cr}$ and each of $\mathrm{Ni}$ and $\mathrm{V}$; and the good correlation between it and each of $\mathrm{Ti}$ and $\mathrm{Fe}$, as well as association of $\mathrm{Cr}$ with these four elements in Factor $\mathrm{F} 1$ probably indicate that the association of these elements are not controlled by environmental factors in the residual soils but, perhaps, by their presence in a primary source from which the residual soils are derived. In other words, the elemental association in the residual soil in this case is inherited from the underlying bedrock.

All the samples analyzed contain Fe in concentration that ranges from 0.12 to $12.33 \%$ with a mean of $2.46 \%$. With the selected threshold of $9.5 \%$, only one anomalous value occurs at sample sites DPS38 (12.33\%) that is underlain by quartz biotite schist (Fig. 3). Compared with the background concentration of Fe in soils (Table 5), this anomalous site is insignificant. This might be a pointer to absence of iron deposit in the study area. The high correlation of Fe with either Mo or V, good correlation that exists between $\mathrm{Fe}$ and each of $\mathrm{Cr}$, $\mathrm{Ni}$ and $\mathrm{Ti}$ and fairly good correlation of Fe with $\mathrm{Co}$ and $\mathrm{Mn}$, as well as association of Fe with the elements in Factors F-1 and F-3 might indicate its ubiquity in geological materials and co-precipitation and/or adsorption of these elements with Fe oxides in the soils, a secondary geochemical environment.

All the samples analyzed contain Mn contents that range from 16 to 1159 ppm with a mean of 306 ppm. With the selected threshold of $1545 \mathrm{ppm}$, no anomalous $\mathrm{Mn}$ values occur in the region. Compared with the background concentration of $\mathrm{Mn}$ in the crustal soils (Table 5), the mean Mn concentration of the soils of the district is low. Therefore, one can infer there is no Mn mineralization in the underlying bedrock of the district. However, the high correlation between $\mathrm{Mn}$ and any of $\mathrm{Co}, \mathrm{Fe}, \mathrm{Mo}, \mathrm{Ni}$, Ti and V, as well as the association of Mn with Co and $\mathrm{Ni}$ in Factor F-2, and Fe, Ti and V in Factor F-3 strongly suggests that Mn oxides must have scavenged the other elements or coprecipitated with them in the soils of the district.

Mo is present in detectable amounts in forty-eight samples and below the lower limit of detection of $0.01 \mathrm{ppm}$ in one sample. It ranges in concentration from 0.04 to $2.82 \mathrm{ppm}$ with a mean value of $0.68 \mathrm{ppm}$. At the selected threshold value of $3.8 \mathrm{ppm}$ (Table 2), no anomalous values exist for Mo in the region. A comparison of the average abundance of Mo in the World's soils (Table 5) with its mean concentrations in Dagbala-Atte District soils showed that Mo concentration in the latter is generally low. Nevertheless, the high correlation between Mo and each of Fe, Mn and V and also its close association with Fe and V in Factor F-3 probably indicate that the association of Mo, Fe and V is controlled by the soil environmental conditions rather than by inheritance from a primary source (underlying bedrock) in the study area.

$\mathrm{Ni}$ is widely distributed in this district and is detected in all the 49 samples employed for this research. Its contents range from 1.3 to $46.2 \mathrm{ppm}$ with a mean of $12.2 \mathrm{ppm}$. The selected threshold value of $45.6 \mathrm{ppm}$ (Table 2) indicates one anomalous value at site DPS33 (46.2 ppm). This anomalous site is underlain by quartz biotite schist (Figure 3). Ni distribution map indicates $\mathrm{Ni}$ highest site in the southwestern part of the region. The shape of the anomaly is also similar to that of Co. A comparison of the average abundance of Ni in the World's soils (Table 5) with its mean concentrations in Dagbala-Atte District soils showed that Ni anomalous value may be significant in the study area. 


\section{International Advanced Research Journal in Science, Engineering and Technology}

Vol. 6, Issue 3, March 2019

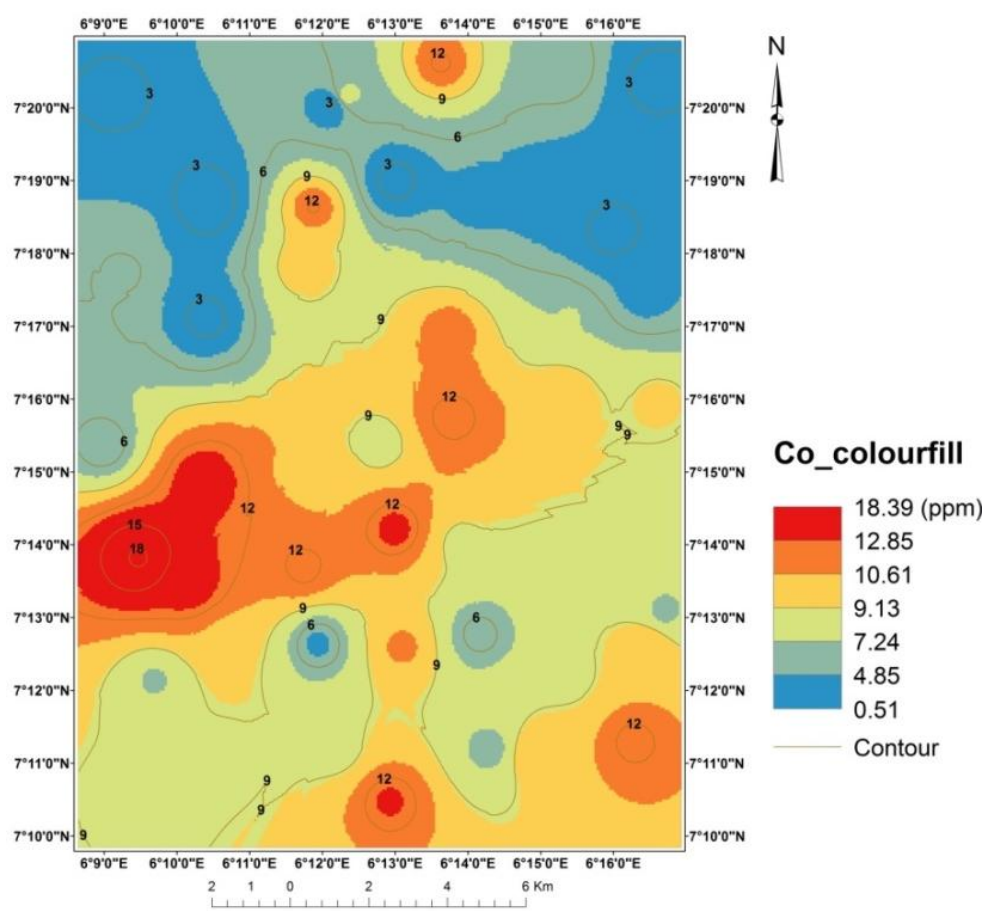

(a)

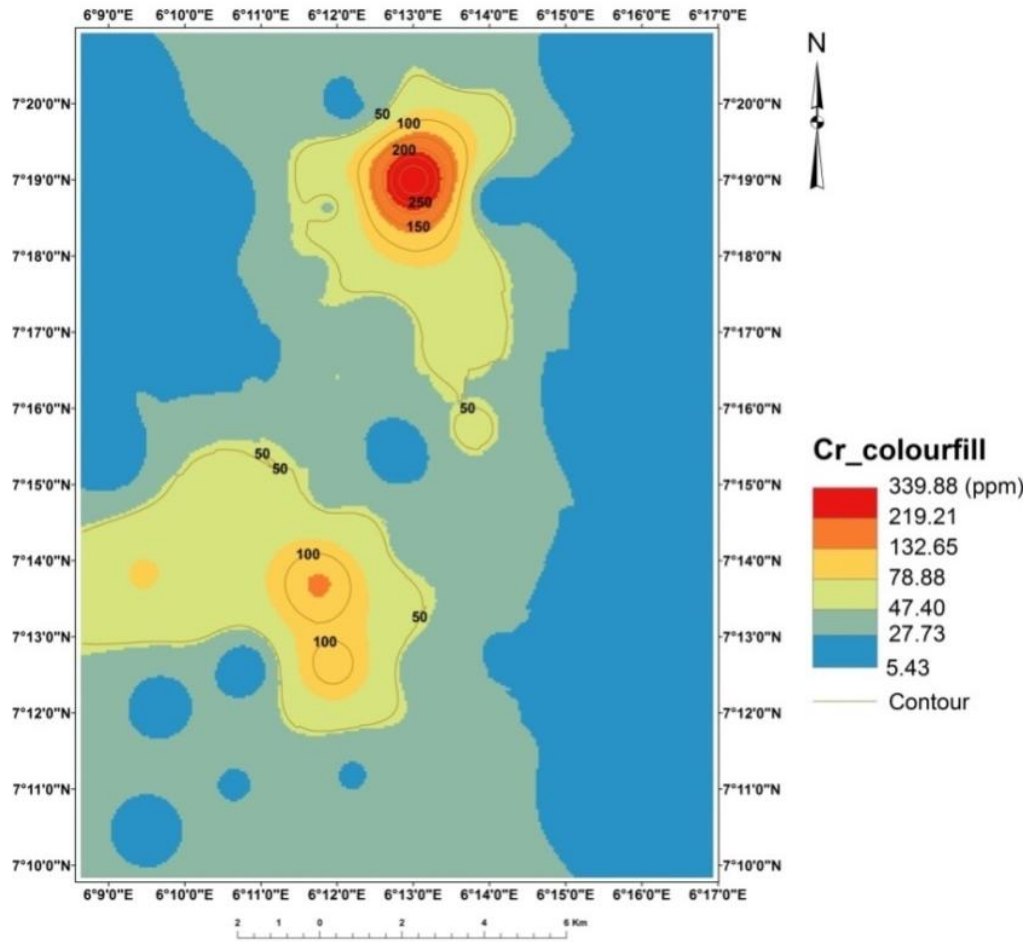

(b)

Figure 6: Geochemical Distribution Maps of (a) Co and (b) Cr in the soils of Dagbala-Atte District. 
International Advanced Research Journal in Science, Engineering and Technology

Vol. 6, Issue 3, March 2019

Table 5: Background Concentration of the Analyzed Trace Elements in Soils and Utility in Geochemical Exploration (Largely After [19, 26].

\begin{tabular}{|l|l|l|l|}
\hline Element & $\begin{array}{l}\text { Background } \\
\text { Concentration in Soils } \\
(\mathrm{ppm})\end{array}$ & Surficial Mobility & Use in Exploration \\
\hline $\mathrm{Co}$ & 10 & Moderate, Mn scavenged & Widely used \\
\hline $\mathrm{Cr}$ & 45 & Low & Chromite in panned concentrates \\
\hline $\mathrm{Fe}$ & & & \\
\hline $\mathrm{Mn}$ & 300 & Moderate, high at low $\mathrm{pH}$ & Scavenges Co, Zn, Ag \\
\hline $\mathrm{Mo}$ & 3 & Moderate to high & Wide use \\
\hline $\mathrm{Ni}$ & 17 & Low, scavenged & Wide use \\
\hline $\mathrm{Ti}$ & & & \\
\hline $\mathrm{V}$ & 55 & Moderate & Little use \\
\hline $\mathrm{W}$ & 1 & Very low & Scheelite fluoresce in UV \\
\hline
\end{tabular}

This suggests that there is a comparatively high concentration of $\mathrm{Ni}$ in the district. The relatively high correlation between $\mathrm{Ni}$ and any of $\mathrm{Cr}, \mathrm{V}, \mathrm{Co}, \mathrm{Ti}, \mathrm{Fe}$, and $\mathrm{Mn}$ and the association of these elements with Ni in Factors F-1 and F-2 probably reflect two types of conditions controlling elemental association in the study area. First, the association of $\mathrm{Ni}$ with $\mathrm{Cr}$ in Factor 1 is most likely related to the inferred $\mathrm{Cr}$ mineralization in the silicified, sheared rock and is probably inherited from the underlying bedrock; secondly, the association of Ni with $\mathrm{Mn}$ and Co in Factor 2 is most probably controlled largely by scavenging and co-precipitation of the elements in the soil environment.

The distribution pattern of $\mathrm{V}$ is fairly diffuse, the range being from 4 to $128 \mathrm{ppm}$ with a mean of 38 ppm. Two anomalous values exist for $\mathrm{V}$ at threshold value of $121.6 \mathrm{ppm}$ at sites DPS11 (128 ppm) and DPS38 (128 ppm) in the study area. These anomalous value sites, DPS11 and DPS38, fall within the silicified, sheared rock and quartz biotite schist, respectively (Fig. 3). Two relatively high V value areas occur at the north- and south-central areas of the district. The one at the north falls in the same anomalous area of $\mathrm{Cr}$ and the other one in the south coincides with the anomalous area of $\mathrm{Co}$ and $\mathrm{Ni}$. Comparing the mean $\mathrm{V}$ concentration in the soils of the district with the average abundance in the World's soils (Table 5), one can say that its two anomalous concentrations are significant, suggesting possible mineralization or concentration of $\mathrm{V}$ with $\mathrm{Cr}$ in the silicified, sheared rock and with the comparatively high $\mathrm{Ni}-\mathrm{Co}$ concentration located in the quartz biotite schist of the district. Nevertheless, the best to fairly good correlation between $\mathrm{V}$ and any of $\mathrm{Cr}, \mathrm{Fe}, \mathrm{Ni}$, Ti and Mo and its association with these elements in Factors F-1 and F-3 may indicate that $\mathrm{V}$ occurs together with these elements in some lithologies in the region.

$\mathrm{W}$ has very high restricted distribution in the study area. It was detected in 6 samples, being present in amounts less than the instrument's lower detection limit of $0.1 \mathrm{ppm}$ in the remaining 43 samples. Where detected, its values ranged from 0.1 to $0.4 \mathrm{ppm}$. As a result of this highly restricted distribution, W was not employed in both the statistical analyses and plotting of geochemical distribution map used for this study. Comparing background concentration of W in World's soils to its concentration in the district soils, no site can be said to contain W mineralization in the district.

\section{SUMMARY AND CONCLUSION}

Geochemical exploration for ferrous metals was undertaken in Dagbala-Atte District by sampling residual soil from 49 sites in a grid pattern. The forty nine soil samples were analyzed for nine ferrous metals comprising $\mathrm{Co}, \mathrm{Cr}, \mathrm{Fe}, \mathrm{Mn}$, $\mathrm{Mo}, \mathrm{Ni}, \mathrm{Ti}, \mathrm{V}$ and $\mathrm{W}$. Our study revealed that $\mathrm{Co}, \mathrm{Cr}, \mathrm{Fe}, \mathrm{Mn}, \mathrm{Mo}, \mathrm{Ni}, \mathrm{Ti}$ and $\mathrm{V}$ are very widely distributed in the study area and were detected in the 49 samples except Mo detected in 48 . W has a highly restricted occurrence as it was detected in only 6 of the 49 samples employed for the study.

Univariate statistical analysis of the geochemical data generated from the sample analyses involved histogram and box plots, which revealed that these ferrous metals are log-normally distributed in the study area. Using the univariate statistical plots the threshold values for eight elements ( $\mathrm{Co}, \mathrm{Cr}, \mathrm{Fe}, \mathrm{Mn}, \mathrm{Mo}, \mathrm{Ni}$, Ti and V) were determined in order to identify elements having anomalous concentrations. By using the threshold values as cut-off points, the anomalous values for the various elements at the sample sites were determined. A comparison of the threshold values obtained with the corresponding background concentrations of these elements in World's soils showed that only four ferrous metals, namely, $\mathrm{Co}, \mathrm{Cr}, \mathrm{Ni}$ and $\mathrm{V}$ have significant anomalous values in the district.

Multivariate statistical analysis of the geochemical data involving correlation matrix and factor analysis enabled recognition of three major groups of elemental association or factors, viz, Cr-Ni-V-Ti-Fe factor F-1, Mn-Co-Ni factor F-2 and Mo-Fe-V factor F-3. On account of high correlation coefficients between metals (Table 3) and high factor loadings of individual elements (Table $4 \mathrm{a} \& \mathrm{~b}$ ) only $\mathrm{Cr}-\mathrm{Ni}-\mathrm{V}$ mineralization is considered probable while the Co-Ni concentration is probably a product of scavenging action of or co-precipitation with $\mathrm{Mn}$ as can possibly be inferred from factor F-2. 


\author{
Vol. 6, Issue 3, March 2019
}

Superimposing the geochemical distribution maps of the various elements in the residual soils on the geological map of the district enables identification of the possible lithologic sources of the four elements (Co, Cr, Ni and V) having significant anomalous values [20,21]. Hence the suspected mineralization and anomalous metallic concentration in the Dagbala-Atte District are linked with different rock types as follows:

1. The suspected $\mathrm{Cr}-\mathrm{Ni}-\mathrm{V}$ mineralization is located in the silicified, sheared rock that occupies the northern and southern parts of the district around Dagbala and Atte.

2. The Co-Ni anomalous concentration is inferred to occur within the quartz-biotite schist that underlies the southwestern part of the district around Sasaro and Egbigele.

Subsequent further studies will focus the areas circumscribed for the suspected mineralization and anomaly in the district and the logical step is to carry out a lithogeochemical survey of these areas.

\title{
REFERENCES
}

[1]. Olade M. A., "General features of a Precambrian iron ore deposit and its environment at Itakpe ridge, Okene, Nigeria". Trans Inst Min Metall 86:B1-B9. 1978

[2]. Adekoya, J. A., "The geology of banded iron-formations in the Precambrian Basement Complex of Northern Nigeria". Ph.D. Dissertation, University of Ibadan, Nigeria. 1990, 421pp.

[3]. Obaje NG, Lar UA, Nzegbuna AI, Moumouni A, Chaanda MS, Goki NG Geology and Mineral Resources of Nasarawa State: an Investors's Guide. Nasara Scientifique (A publication of he Nasarawa State University) 2:1-34

[4]. Shibayan Y (1985) Investigation of possible chromite-bearing serpentinites and associated rocks of $\quad$ NW Nigeria. Unpublished M.Sc. Thesis. Ahmadu Bello University, Zaria, Nigeria

[5]. Muecke A, Okujeni C (1984) Geological and ore microscopic evidence on the epigenetic origin of the manganese occurrences in northern Nigeria. J Afr Earth Sci 2:209-225

[6]. Bafor BE (1981) The occurrence of sulphide mineralization in the Egbe area of South-Western Nigeria. Niger J Min Geol 18:175-179

[7]. Elueze AA (1981) Petrographic studies of metabasic rocks and meta-ultramafites in relation to mineralization in Nigerian schist belts. J Mining Geol 18:31-36

[8]. Adepoju, M. O. and Adekoya, J. A., "Statistical analysis of reconnaissance geochemical data from Global Journal of Geological Science, vol. 6, No. 1, 2008, pp. 63- 74.

[9]. Adepoju, M. O. and Adekoya, J. A., "Reconnaissance geochemical study of a part of Igarra schist belt, $\quad$ southwestern Nigeria," Ife Journal of Science, vol. 13, No. 1, 2011, pp. 75-92.

[10]. Dada, S. S., "Evolution de la croute continentale au Nord Nigeria U-Pb et de traceurs isotopiques Sr, Nd et Pb," These diplome de Doctoral, Univ. der Sci. Tech. Lang. Montpellier, 1989, pp 200.

[11]. Hockey, R. D., Sacchi, R., de Graaff, W. P. F. H. and Muotoh, E. O. G., "The geology of Lokoja-Auchi area; explanation of 1: 250,000 Sheet 62," Geol. Surv. Nigeria. Bull., No. 39, 1986, 71pp.

[12]. McCurry, P., "The geology of the Precambrian to Lower Paleozoic rocks of northern Nigeria - a review," In: C. A. Kogbe (ed.), Geology of Nigeria. Elizabethan, Lagos, 1976, pp. 15-59

[13]. Oyawoye, M.O., "The Geology of the Nigerian basement complex," Nigerian Journal of Mining, Geological and Metallurgical Society (now Journal of Mining and Geology), 1964, 1:87-102.

[14]. Egbuniwe, I. G. and Ocan, O. O., "Selection of fieldwork areas for teaching/training: Igarra area as an example," In: D. O. LambertAikhionbare \& A. I. Olayinka (Editors) Proceedings of Field Mapping Standardization Workshop, 2004, p. 79-95. Ibadan University Press.

[15]. Odeyemi, I. B., "Lithostratigraphy and structural relationships of the Upper Precambrian Metasediments in Igarra area, southwestern Nigeria," In: Oluyide, P. O., W. C. Mbonu, A. E. Ogezi, I. G. Egbuniwe, A. C. Ajibade, and A. C. Umeji. （Editors), Precambrian Geology of Nigeria. Publ. GSN, 1988, p. $111-125$.

[16]. Odeyemi, I.B., "On the petrology of the Basement Complex Rocks of Bendel State, Nigeria," Ph.D. Dissertation, University of Ibadan, Nigeria. 1977, 239pp.

[17]. Odeyemi, I.B., "Preliminary report on the field relationships between the Basement Complex rocks in Igarra, Midwestern Nigeria," In: Kogbe, C.A (Ed) Geology of Nigeria, 1976, p. 59-63 Elizabethan Publ. Co. Lagos, Nigeria.

[18]. Adepoju, M.O., "Geological and Geochemical Exploration Studies in Dagbala-Atte District in Igarra $\quad$ Schist $\quad$ Belt, Southwestern Nigeria," PhD Dissertation, FUTA, Nigeria, 2017.

[19]. Levinson, A. A., "Introduction to exploration geochemistry,". Applied Publication Limited, Calgary, 1974, pp. 1965

[20]. Adepoju, M.O., Adekoya, J.A. and Odeyemi, I.B., "Statistical Evaluation of Soil Geochemical Data $\quad$ from Dagbala-Atte District in Igarra Schist Belt, Southwestern Nigeria,". Geoinformatics and Geostatistics: An Overview, 2018, 6:3.

[21]. Adesiyan A, Adekoya A, Akinlua A and Torto N "Statistical Studies of Soil Geochemical Data from Gbongan-Odeyinka Area, SouthwesternNigeria," Geoinfor Geostat: An Overview, 2014, $\quad 2: 1$.

[22]. Odokuma AO, Adekoya JA, "Factor analysis of stream sediment geochemical data from $\quad$ Onyami $\quad$ drainage system, Southwestern Nigeria. I J GeoSci, 2013, 4: 656-661.

[23]. Ajayi TR, "Statistical analysis of stream sediment data from the Ife-Ilesha Area of Southwest Nigeria," J Geochem Explor, 1981, 15: 539-548.

[24]. Sadeghi, M., Billay, A. and Carranza, E. J. M., "Analysis and mapping of soil geochemical anomalies: implications for bedrock mapping and gold exploration in Giyani area, South Africa," Journal of Geochemical Exploration, 2015, 154, pp. 180-193 doi: 10.1016/j.gexplo.2014.11.018.

[25].Tukey, J.W., "Exploratory Data Analysis,” Addison-Wesley. 1977.

[26].Rose, A. W., Hawkes, H. E. and Webb, J. S., "Geochemistry in mineral exploration," 3rd Edition,Academic Press, London, 1991, 711 p. 